\title{
LINGUOCULTURAL SPECIFITY OF PHRASEOLOGICAL UNITS IN THE PROCESS OF TEACHING LANGUAGES
}

\author{
ESPECIFICIDADE LINGUOCULTURAL DAS UNIDADES FRASEOLÓGICAS NO \\ PROCESSO DO ENSINO DE LÍNGUAS
}

\author{
ESPECIFICIDAD LINGUOCULTURAL DE LAS UNIDADES FRASEOLÓGICAS EN EL \\ PROCESO DE ENSEÑANZA DE LENGUAS
}

\author{
Aida R. NURUTDINOVA ${ }^{1}$ \\ Dina P. SHEININA ${ }^{2}$ \\ Vilena R. GAGARINA ${ }^{3}$ \\ Muhammad YOUSAF ${ }^{4}$
}

\begin{abstract}
In modern linguistics, there is a great interest in the analysis of linguistic and cultural material in the process of teaching languages, an anthropocentric paradigm is formed, the language is considered not only within its communicative and cognitive function, but as a kind of cultural code of individual linguistic and cultural communities. The purpose of this scientific article is to study the manifestation of linguistic and cultural worldview and to study the linguistic and cultural aspect of learning English through phraseological level units. The study of the conceptual structure allows us to identify deeper and more significant properties of an object or phenomenon. Such properties represent generalized features of an object or phenomenon that are considered the most important and necessary for their identification, since the features of an object or phenomenon form the structure of the concept. The object of this scientific article is phraseological units that express the concepts of the inner world of a person, the specifics of their functioning and interpretation in the English language, and aspects of their use in the process of teaching English. All the subtleties of a nation's culture are reflected in its language, which is specific and unique since it captures the world and the person in it in different ways (BUYANOVA, 1998). "Therefore, the problem of the relationship between language and culture occupies one of the Central places in the problems of research conducted in the field of linguoculturology and cognitive science.". Linguoculturology is the branch of linguistics that emerged at the intersection of linguistics and cultural studies and exploring the manifestations of the culture of the people, which were reflected and fixed in the language (VERESHCHAGIN, 1982).
\end{abstract}

KEYWORDS: Teaching languages. Linguocultural phraseological. Individual linguistic.

\footnotetext{
${ }^{1}$ Kazan Federal University (KPFU), Kazan - Russia. Associate Professor of the Department of Contrastive Linguistics. Candidate of Pedagogical Sciences. ORCID: https://orcid.org/0000-0001-5759-0820. Email: airnurutdinova@kpfu.ru

${ }^{2}$ Kazan Federal University (KPFU), Kazan - Russia. Assistant of the Department of Contrastive Linguistics. ORCID: https://orcid.org/0000-0001-6531-448X. E-mail: dina.shejnina@ksu.ru

${ }^{3}$ Kazan Federal University (KPFU), Kazan - Russia. Senior Lecturer of the Department of Contrastive Linguistics. ORCID: https://orcid.org/0000-0003-4533-3442. E-mail: vrgagarina@kpfu.ru

${ }^{4}$ Abdul Wali Khan University (AWKUM), Mardan - Pakistan. Associate Professor. Candidate of Pedagogical Sciences. ORCID: https://orcid.org/0000-0001-6978-0488. E-mail: muhammadyousafparacha@yahoo.com
}

Rev. EntreLínguas, Araraquara, v. 7, n. esp. 1, p. 126-134, fev. 2021. e-ISSN: 2447-3529 
RESUMO: Na linguística moderna, há um grande interesse na análise de material linguístico e cultural no processo de ensino de línguas, forma-se um paradigma antropocêntrico, a língua é considerada não apenas dentro de sua função comunicativa e cognitiva, mas como uma espécie de código cultural de comunidades linguísticas e culturais individuais. O objetivo deste artigo científico é estudar a manifestação da visão de mundo linguística e cultural e estudar o aspecto linguístico e cultural da aprendizagem do inglês por meio de unidades de nível fraseológico. $O$ estudo da estrutura conceitual nos permite identificar propriedades mais profundas e significativas de um objeto ou fenômeno. Tais propriedades representam características generalizadas de um objeto ou fenômeno que são consideradas as mais importantes e necessárias para sua identificação, uma vez que as características de um objeto ou fenômeno formam a estrutura do conceito. O objeto deste artigo científico são as unidades fraseológicas que expressam os conceitos do mundo interior de uma pessoa, as especificidades de seu funcionamento e interpretação na língua inglesa e aspectos de seu uso no processo de ensino de inglês. Todas as sutilezas da cultura de uma nação se refletem em sua linguagem, que é específica e única, pois capta o mundo e a pessoa que nele se encontra de diferentes maneiras (BUYANOVA, 1998). «Portanto, o problema da relação entre língua e cultura ocupa um dos lugares centrais nos problemas da investigação realizada no campo da linguoculturologia e das ciências cognitivas". A linguoculturologia é o ramo da linguística que surgiu na intersecção da linguística e dos estudos culturais e explorando as manifestações da cultura do povo, que se refletiam e se fixavam na língua (VERESHCHAGIN, 1982).

PALAVRAS-CHAVE: Ensino de línguas. Frases linguísticas e culturais. Linguística individual.

RESUMEN: En la lingüistica moderna existe un gran interés por el análisis del material lingüistico y cultural en el proceso de enseñanza de las lenguas, se forma un paradigma antropocéntrico, se considera la lengua no solo dentro de su función comunicativa y cognitiva, sino como una especie de código cultural de las comunidades lingüísticas y culturales individuales. El propósito de este artículo científico es estudiar la manifestación de la cosmovisión lingüistica y cultural y estudiar el aspecto lingüistico y cultural del aprendizaje del inglés a través de unidades de nivel fraseológico. El estudio de la estructura conceptual nos permite identificar propiedades más profundas y significativas de un objeto o fenómeno. Tales propiedades representan características generalizadas de un objeto o fenómeno que se consideran las más importantes y necesarias para su identificación, ya que las características de un objeto o fenómeno forman la estructura del concepto. El objeto de este artículo científico son las unidades fraseológicas que expresan los conceptos del mundo interior de una persona, las especificidades de su funcionamiento e interpretación en el idioma inglés, y aspectos de su uso en el proceso de enseñanza del inglés. Todas las sutilezas de la cultura de una nación se reflejan en su lenguaje, que es específico y único ya que capta el mundo y la persona en él de diferentes formas (BUYANOVA, 1998). «Por tanto, el problema de la relación entre lengua y cultura ocupa uno de los lugares centrales en los problemas de la investigación realizada en el campo de la lingüoculturología y las ciencias cognitivas. La linguoculturología es la rama de la lingüistica que surge en la intersección de la lingüistica y los estudios culturales y explora las manifestaciones de la cultura de las personas, que se reflejaban y fijaban en la lengua (VERESHCHAGIN, 1982).

PALABRAS CLAVE: Enseñanza de idiomas. Fraseológico lingüístico-cultural. Lingüística individual. 


\section{Introduction}

The concept of "language and culture" converges the interests of all human sciences, this is a cross-cutting idea that blurs the boundaries between the disciplines that study human beings, since it is impossible to study a person outside (out) of his language. The object of linguocultural science is the study of the language interconnection and people culture. As a result, it forms the national picture of the world. Moreover, the concepts of the language are reflected in folklore, mythology, and literature (HUSNUTDINOV et al., 2019). Regardless of belonging to a particular scientific school, all researchers of culture recognize the exceptional role of language in the structure of this complex phenomenon. A language is the main form of expression and existence of national culture.

The first definitions of culture were based on the idea that culture is a homogeneous phenomenon inherent in all societies. Differences in societies were interpreted not as differences in essence, in content, but as differences in the degree of development of the same phenomenon - culture. Progress from barbarism to civilization served as a measure of cultural development. The more signs of civilization a society had, the more culturally advanced it was considered to be. The most striking expression of this approach to understanding culture can be found in the works of E. Tylor. His widely quoted definition of culture describes it as a complex phenomenon, including knowledge, faith, art, morality, law, customs and any other traits and habits acquired by a person as a member of society (HOOPER; THOMSON, 1973).

Thus, a language, thought and culture are so closely interlinked that they almost form a whole unit consisting of three components, none of which can function (and therefore exist) without the other two. Together, they relate to the world around them, reflect and simultaneously shape it. At the same time, they form so-called the world pictures.

The relationship between language and culture can be seen as a relationship between a part and a whole. Language can be perceived as a component of culture and as an instrument of culture (which is not the same thing). However, language is at the same time autonomous in relation to culture as a whole, and it can be considered as an independent, autonomous semiotic system, i.e. separate from culture, that can be seen in traditional linguistics. Since every native speaker is also a culture representative, language signs acquire the ability to perform the function of cultural signs and thus serve as a means of representing the main cultural attitudes (VERESHCHAGIN; KOSTOMAROV, 1983). That is why the language is able to display the cultural and national mentality of its speakers. 
The categorical linguistics system is a vast corpus of concepts, many of which allow ambiguous interpretation. Linguistics is a complex of sciences, and it is common to recognize that specialists in one field of language science do not understand their colleagues who are developing problems in another field. This is especially true for new complex branches of linguistics, such as socio-and psycholinguistics, cognitive linguistics, text and discourse linguistics, cultural linguistics.

Therefore, linguoculturology is a discipline that studies the manifestation, reflection and fixation of culture in language (VOROBYOV, 1999). The linguo-cultural approach to the explanation of a word in a text "is descriptive in its essence, a particular phenomenon is axiomatically qualified as culturally significant, and the explanation is transferred from the sphere of language to the sphere of history, mythology, and folklore. From the unique and specific form of world fixing with language signs, the idiomatic character of the language sign acts as the linguocultural language coordinate.

In our opinion, the center of interests of linguoculturology is "the study and description of the interaction of language and culture in the range of modern cultural and national identity and its iconic presentation. This synchronous orientation significantly distinguishes it from ethnolinguistics, which, first of all, takes into account the specific, national, folk, and tribal features of the ethnos. At the same time, when the goals and objectives of ethnolinguistics and linguoculturology differ, the former acts as the foundation for the latter. This is due to the historical nature of both culture and language: the cultured worldview displayed in language signs is usually imprinted in their internal form, and this is especially evident in the figuratively motivated basis of phraseological units. It is transmitted by them from generation to generation and brings to the modernity the collective ideas that were formed in the processes of cultural development of the world by an ethnic group, people, nation".

\section{Results and discussion}

In our research, we adhere to the opinion of scientists that the subject of linguoculturology is the units of language and discourse that have acquired a symbolic, reference, figurative and metaphorical meaning in culture and that generalize the results of human consciousness itself-archetypal and prototypical, recorded in myths, legends, rituals, folklore, religious discourses and etc. At the same time, one linguistic and cultural unit can simultaneously belong to several semiotic systems: the stereotype of the ritual can become a proverb, and then turn into a phraseology, for example: go to Tula with your samovar - in 
Russian, in English - to carry coals to Newcastle, means "to carry something to where it is enough". Newcastle is the center of the English coal industry.

Due to the appearance and development of linguoculturology, the national-cultural specificity of phraseological units has become the object of researchers ' close attention. A significant number of studies that have appeared in recent years on the cultural and conceptual features of phraseological units and their role in the formation and reproduction of the cultural identity of an ethnic group, people, or nation indicate the prospects of a linguo-cultural and linguistic approach to the study of phraseology.

The works of linguoculturologists describe various methods of linguoculturological analysis (comparative, comparative-historical, etymological, component analysis and culturalhistorical commentary).

In our opinion, the method of cultural and historical commentary is based on the principles of studying vocabulary and phraseology in connection with the material and spiritual culture and history of the people. In native language lessons, it can be implemented as a cultural and historical commentary on phraseological units with national and cultural specifics.

Phraseological units with national and cultural features (specifics, semantics, components) are usually understood as such phraseological units that contain information about the cultural identity of a native speaker. Such phraseological units are the source of cultural information about the language of this nation, about the features of the people who are native speakers of English, which is especially important in the process of teaching a foreign language. Here is an example of the phraseological unit "house-full Cup" (i.e. someone lives in complete contentment) - someone lives in contentment; someone's house is the incarnation of plenty (a cup filled to the brim and running over, a treasure - trove). This phraseology also refers to the concept of the material world of man, to the segment "home-housing" (BUYANOVA, 1998).

Studying phraseological units in foreign language lessons with national and cultural specifics and accompanying them with the necessary commentary - information about their cultural and historical significance makes it possible to enrich the dictionary, as well as solve the following tasks: 1) increase motivation to study native and foreign languages; 2) arouse students ' interest in the cultural facts of language phenomena.

A special importance is the study of this linguistic and cultural material that has a small but significant life experience, the skills of comparative analysis of language phenomena. Phraseological units, winged expressions, idioms that perfectly represent the linguistic and cultural aspect of learning a foreign language, which encode knowledge about the history, modern social life, culture, everyday life and traditions of the language group being studied - 
are a huge help in this. High school age is the time to develop views and beliefs, to form a worldview. In connection with the need for self-determination, there is a need to understand yourself and your environment (Tarasov, 1999). The use of cultural and historical commentary in foreign language lessons in the process of dictionary and semantic work necessarily implies an appeal to the history of the people. As a result of familiarization with phraseological units, additional extralinguistic knowledge about the culture of a native speaker is gradually accumulated in the minds of students.

In practice, the acquisition of a foreign language is inextricably linked with the introduction to a foreign language culture. In the process of teaching a foreign language, elements of country studies are combined with language phenomena that act not only as a means of communication, but also as a way to familiarize students with a new reality for them. Thus, along with mastering a foreign language, cultural knowledge is acquired and the ability to understand the mentality of native speakers of another language is formed. If a few years ago it was recognized that the use of extralinguistic factors indicates a certain "failure" or "weakness" of the linguist-researcher, now the need to learn a language in its real functioning in various spheres of human activity has become generally accepted, when students consciously perceive information, operate with knowledge and skills.

\section{Summary}

As a branch of linguistics and linguodidactics that combines elements of linguistics (revealing the semantics of language units) with elements of country studies (studying the reality of a country through the words that denote them), language studies лингвострановедение include language training and provide certain information about the country of the language being studied. Linguistics is a special branch of the multidimensional science of language and society - sociolinguistics. However, in contrast to sociolinguistic studies, where the direct object of analysis is the socio-determined variability of the language structure of a social group within a nation, linguistics studies elements of national culture that are expressed in a literary language standard serving the entire nation. Linguo-cultural studies is designed to provide communicative competence in acts of intercultural communication, primarily through an adequate perception of speech and understanding of the original texts. Communication theory assumes relative equality of interlocutors in terms of possession of some information: in addition to a common language (in purely structural and largely semantic terms of its components), they must have some common volume of extralinguistic knowledge, which 
forms the basis of communication. At the same time, cultural and country-specific value, typicity, common knowledge and orientation to modern reality, thematicality and functionality of phenomena are the most important criteria for selecting the national-cultural component of the content of foreign language teaching.

A learner of a foreign language is a bearer of his culture, but his background knowledge can be enriched, acquiring the elements of culture of the studied language; he thereby becomes in some way a carrier of a world culture, begins to understand better and appreciate his own culture. Background knowledge as the main object of linguo-cultural studies was considered by many scientists and teachers of practice in their works. Of course, we can not deny that all the achievements of linguistics meet the goals and objectives of the methodology of teaching foreign languages and are currently widely used. However, we cannot underestimate the fact that by turning to linguistics as a science, we touch on such a wide range of problems that scientists from different fields of knowledge are currently working on: linguists, psychologists, psycholinguists, sociologists, sociolinguists. For example, linguistics studies consider "background knowledge" as a poorly studied component of word semantics, hence the linguistic orientation of research. An associative experiment widely used in psycholinguistics is used as one of the methods for objectifying background knowledge. Within the framework of the same science, the problem of the ratio of social and personal in the construction of a communicative act is also solved.

\section{Conclusions}

All this allows us to conclude that a significant range of problems and emerging research prospects expand the boundaries of linguistics and make it a complex science. Linguistics has a lot of unresolved issues, a significant part of which is problematic. Their complexity and multi-aspect nature does not allow us to give exhaustive answers to all of them, to develop a certain point of view. Probably, for this reason, sometimes there is some inconsistency in the authors ' judgments, since the question of defining the boundaries of background knowledge is not completely resolved, sometimes it includes almost all the knowledge that people have at the time of communication.

The cumulative function of a foreign language is most clearly manifested in the field of vocabulary, since it is directly related to the objects and phenomena of the surrounding reality. The lexical system is largely determined by the categories of the material world and social factors. 
The English language has a large number of phraseological units that have a literary origin, many of them are widely used in everyday colloquial speech. Every Englishman from childhood knows such phraseological phrases from the books of L. Carroll "Alice in Wonderland", "Alice through the looking glass", as: to smile like a Cheshire cat-to smile up to the ears; mad as a hatter - to go mad.

Famous Shakespearean plays are also of great interest:

a fool's paradise ("Romeo and Juliet") - a world of fantasy, ghostly happiness; give the devil his due ("King Henry V") - pay tribute to the enemy; the observed of all observers ("Hamlet") - the center of universal attention, and many others (VINOGRADOV, 1953).

According to the authors, the most difficult group in terms of determining their national and cultural content is formed by the background vocabulary. It is well known that if we compare the concept-equivalent words in different languages, they will differ from each other due to the fact that each of them is associated with a certain set of knowledge.

Russian scientists also pay attention to this problem offering certain approaches for better teacher student interaction. For instance, Khakimzyanova D.F. E.K.Shamsutdinova, Melnikova O.K. study project-based approaches to teaching ESL at Kazan Federal University. In other works, Melnikova O.K. and her colleagues propose game-based approach and flipped classroom approach to teaching ESL in higher school (BLAGOVESHCHENSKAYA et al., 2019).

ACKNOWLEDGEMENTS: The work is performed according to the Russian Government Program of Competitive Growth of Kazan Federal University.

\section{REFERENCES}

BLAGOVESHCHENSKAYA, A.; AINOUTDINOVA, I.; NURUTDINOVA, A.; DMITRIEVA, E. The research of the stylistic peculiarities of represented speech for better teacher-student interaction at English literature classes. In: INTERNATIONAL TECHNOLOGY, EDUCATION AND DEVELOPMENT CONFERENCE, 13., 2019, Valencia. Proceedings [...]. Valencia, Spain: INTED, 2019. p. 5044-5049.

BUYANOVA, L. Y. Russian phraseology as a mental and cognitive means of linguistic conceptualization of the sphere of moral qualities of the individual»-Krasnodar. KubSU, p. 3$14,1998$.

HOOPER, J.; THOMSON, S. On the applicability of root transformations. Linguistic research. Tom., v. 4, n. 4, 1973. 
HUSNUTDINOV, D.; SAGDIEVA, R.; SAYFULINA, F.; GATIN, R.; TIMERKHANOV, A. Phraseological units in the tatar language containing the component of can (Küñel)(SOUL). XLinguae, v. 12, n. 2, p. 41-50, abr. 2019. DOI:

https://doi.org/10.18355/XL.2019.12.02.04

TARASOV, E. F. Language and culture: methodological problems. Language-CultureEthnicity. Moscow: Nauka, 1999. p. 11-129.

VERESHCHAGIN, E. M.; KOSTOMAROV, V. G. Linguistics and the principle of communication. Lingvostranovedcheskoe description of the English language vocabulary. Moscow, 1983. p. 3-113.

VERESHCHAGIN, E.M.; KOSTOMAROV, V.G. National-cultural semantics of Russian phraseological units. Dictionaries and linguostrannovedenie: SB. nauch. Moscow, 1983. p. 89-98.

VINOGRADOV, V. V. Main types of lexical meanings of the word. 1953. n. 5, p. 88-119.

VOROBYOV, V. V. Linguoculturology in the circle of other Humanities. Russian Language Abroad, n. 3, p. 95-101, 1999.

\section{How to reference this article}

NURUTDINOVA, A. R.; SHEININA, D. P.; GAGARINA, V. R.; YOUSAF, M. Linguocultural specifity of phraseological units in the process of teaching languages. Rev. EntreLínguas, Araraquara, v. 7, n. esp. 1, p. 126-134, fev. 2021. e-ISSN: 2447-3529. DOI: https://doi.org/10.29051/el.v7iEsp1.14879

Submitted: $28 / 10 / 2020$

Required revisions: $19 / 12 / 2020$

Approved: $13 / 01 / 2021$

Published: 28/02/2021 